\title{
INVESTIGATION ON EFFECT OF AIR VELOCITY IN TURBULENT NON-PREMIXED FLAMES
}

\begin{abstract}
In this study, the turbulent non-premixed methane-air flame is simulated to determine the effect of air velocity on the length of flame, temperature distribution and mole fraction of species. The computational fluid dynamics (CFD) technique is used

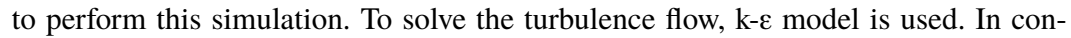
trast to the previous works, in this study, in each one of simulations the properties of materials are taken variable and then the results are compared. The results show that at a certain flow rate of fuel, by increasing the air velocity, similar to when the properties are constant, the width of the flame becomes thinner and the maximum temperature is higher; the penetration of oxygen into the fuel as well as fuel consumption is also increased. It is noteworthy that most of the pollutants produced are NOx, which are strongly temperature dependent. The amount of these pollutants rises when the temperature is increased. As a solution, decreasing the air velocity can decrease the amount of these pollutants. Finally, comparing the result of this study and the other work, which considers constant properties, shows that the variable properties assumption leads to obtaining more exact solution but the trends of both results are similar.
\end{abstract}

\section{Introduction}

Turbulent combustion is an essential occurrence in industrial applications, as in diesel engines, gas turbines, spark-ignition engines, furnaces, and low NOx burners. As the applications are required to be clean, economical, and effective, enhancements are often necessary. Thus, better understanding of turbulent combustion is required. Simulations of a numerical nature known as the Computational Fluid Dynamics (CFD) assist in optimizing and improving the applications found in the reacting flows. CFD is comparatively less

\footnotetext{
${ }^{1}$ Department of Mechanical Engineering, College of Engineering, Yasooj Branch, Islamic Azad University,Yasooj,Iran; Emails: z.namazian@gmail.com,z.namazian@iauyasooj.ac.ir
} 
expensive compared to the experimental studies. Even though a total turbulent reacting flow simulation that includes the entire physical occurrence is currently impossible, the CFD solutions are able to facilitate the design and device-scale analyses of most of the new industrial combustion applications. Turbulent combustion models are obviously necessary for industrial applications. Non-premixed turbulent combustion models are used in many diesel engines and gas-turbine companies for the design tool. Reviews of Libby and Williams [1], Williams [2], Bilger [3], Jones and Whitelaw [4], Peters [5] and the other researchers on non-premixed turbulent combustion exist in literature.

Early studies on turbulent combustion are based on the k- $\varepsilon$ turbulence model [6]. The k-e turbulence model is still an efficient model in many applications. In non-premixed combustion modeling, the first studies were concentrated on the assumption of fast chemistry where equilibrium chemistry is used. Recently, there are several models, which are used for the non-premixed turbulent combustion. The flamelet model [7], the probability density function transport equation approach [8] and the Conditional Moment Closure model (CMC) [9] are the most commonly found models.

Some researchers documented the impact of the velocity ratio of the air-fuel on the features of the Normal Diffusion Flames (NDF) and the Inverse Diffusion Flame (IDF). Mahesh and Mishra [10, 11] performed the first detailed assessment using an experimental research. The turbulent Liquefied Petroleum Gas (LPG) was known as having the feature of inverse diffusion flame stabilization in a back-step burner according to the dual flame structure, the visible flame length, the temperature distribution of the centerline, and the concentration of oxygen. Fernández et al. [12] conducted a numerical research on the lift-off and blowout of methane flame jet diffusion of parallel streams of methane diluted with air and nitrogen. Meunier et al. [13] examined NOx emission from flames of turbulent propane diffusions. The research involved both experimental measures as well as numerical 2D simulations, and had the objective of providing a better understanding of the dominant physical impacts linked to the NOx production in the turbulent diffusion flames. According to Santos and Costa [14], jet diffusion flames can be characterized into three fuels experimentally including methane, propane gases and ethylene based on height of flame lift-off, length of flame as well as NOx emissions.

The study by Sobiesiak et al. [15] documented the impact of air and diameters of fuel jet, inner air jet ratio and outer fuel jet velocities on distribution of temperature, stability limits and flame length on inversely diffused flames. Sze [16] investigated the aspects of appearance, distribution of temperature and NOx emissions of two inversely diffused flames. One had ports that were arranged circumferentially while the other has co-axial jets and both burned using Liquefied Petroleum Gas (LPG). 
A lot of research has been [17-20] conducted on the numerical and experimental effect of hydrogen and methane jet on temperature distribution, stability, and NOx emissions. A research by Jeongseog et al. [17] examined the impact of acoustic excitation and nitrogen dilution on NOx emission and the stabilization of the flames of turbulent diffusion. It was concluded that the propagation velocity of the turbulent flame went up as the nitrogen diluent gas's mole fraction went down. Nevertheless, nitrogen dilution is identified by a reduced mixture of fraction and lowered velocity of burning. This premixing impact results in a lowered flame temperature and a lowered production of NOx. When the length of flame decreases with the excitation of the acoustic, NOx emission is lowered and minimized at the frequency of resonance. The study by Mishra and Kumar [18] examined the impact of adding $\mathrm{H} 2$ on the length of flame, the fraction of soot free length, fraction radiant, temperature of gas, and NOx emission in the LPG consisting of 30\% C4H10 and 69\% C3H8 of jet diffused flame. Another study by El-Ghafour [20] carried out an experimental examination of the turbulent natural diffusion flame of the gas-hydrogen jet and found the impact of adding hydrogen on the flame's stability, length, structure, exhaust species concentrations and emissions of pollutants.

Several other experimental researches [21-23] on the features of high temperature diluted combustion of air have revealed that it results in a very low emission of NOx, low luminosity, improved flame stability, larger flame volume and a better uniformed temperature. Several researches documented the flame control using the inclined oxygen jets [24]. This notion improves the premixed fuel-oxidants and thus lowers the NOx emissions. The turbulent non-premixed methane-air flame has been simulated by [25] to determine the effect of air velocity on the length of flame.

In relation to the turbulent methane-air flame, abundance of experimental and numerical works have been done, but the effects of air velocity on length of the flame, the temperature distribution and mole fraction species are not addressed in detail yet, and no one considers variable properties in its simulation. In this work, the computational fluid dynamics is used to model the turbulent methane-air flame to investigate the effect of air velocity on length of the flame, the temperature distribution and mole fraction species.

\section{Numerical simulation}

In this study, the system of equations (the steady equations for conservation of mass, momentum, energy, and species) has been numerically solved by the application of a 2D double precision model using CFD code based on finite volume procedure. The equations are discredited using Presto's scheme, which is similar to the staggered-grid scheme with a first-order upwind scheme for the 
convective terms. The simple algorithm is used to solve the coupling between continuity and momentum through pressure. The convergence criterion in each case was $\left(\phi^{(i+1)}-\phi^{(i)}\right) / \phi^{(i)}<10^{-8}$, where $i$ denotes the iteration number and $\phi$ could stand for any of the dependent variables. The geometry used in the work by Brookes and Moss [23] is used in this study and shown in Fig. 1. The nonuniform density of nodes for network around the reaction zone (central line and input) is used. Fuel flows with specific rate through the center of chamber at radius $0.003 \mathrm{~m}$ and air flows between two circles of radius $0.003 \mathrm{~m}$ and $0.009 \mathrm{~m}$, respectively. The space between the two cylinders of radius $0.009 \mathrm{~m}$ and $0.25 \mathrm{~m}$ is filled by still air which is in contact with the surrounding environment. The

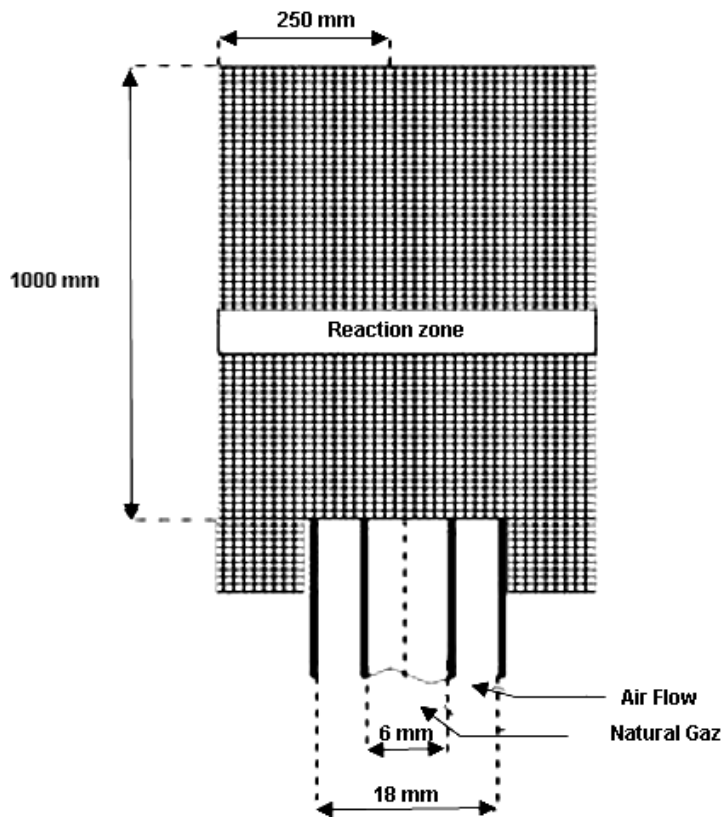

Fig. 1. Flow geometry used in this work

following boundary conditions are applied. Inlet velocity and temperature of air (oxygen) are $7 \mathrm{~m} / \mathrm{s}$ and $300 \mathrm{~K}$, respectively. Besides, for examination of the effect of air velocity on the flame, the speed of $10 \mathrm{~m} / \mathrm{s}$ for the air is also tested. It is notable that the secondary air condition is selected as pressure inlet. Inlet temperature and inlet velocity of fuel (methane) are $10 \mathrm{~m} / \mathrm{s}$ and $300 \mathrm{~K}$, respectively and the directions of flow of air and fuel are the same. The output of current condition can be selected as pressure outlet. Computation using networks with different node density to determine the optimal grid, which has the desired accuracy and minimum computation time, is performed. Finally, $100 \times 200$ grid was selected. 


\section{Results and discussion}

\subsection{Model validation}

In order to evaluate the model used in this work, the temperature profile along radius of the chamber for several axial locations has been compared with a temperature profile of the experimental work by Brookes and Moss [23] and the numerical work by Zouhair et al. [26] as shown in Fig. 2. According to Fig. 2, the numerical results are compared with experimental data, which shows a good compatibility. In order to consider the variable properties in the present work, the data has to be closer to the experimental data compared to other numerical work.

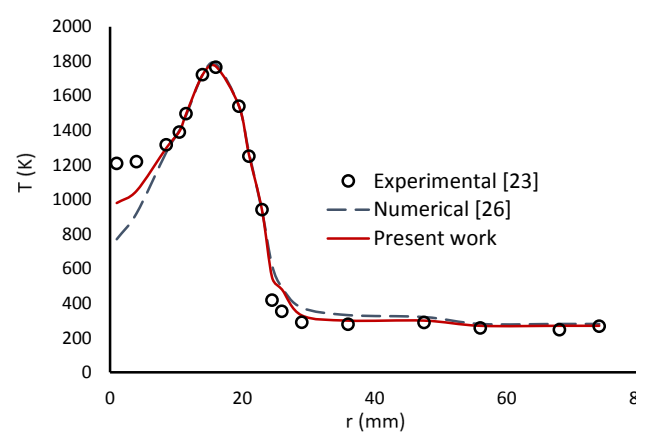

(a) $x=15 \mathrm{~cm}$

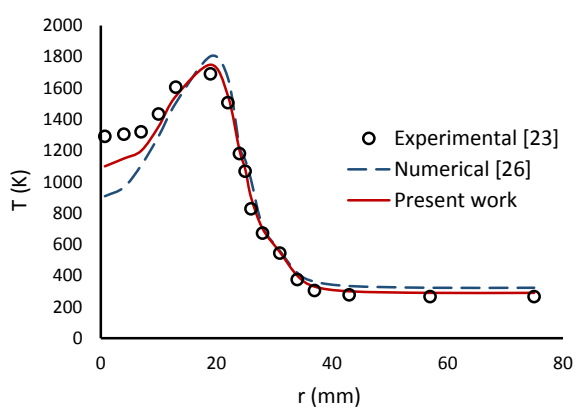

(b) $x=20 \mathrm{~cm}$

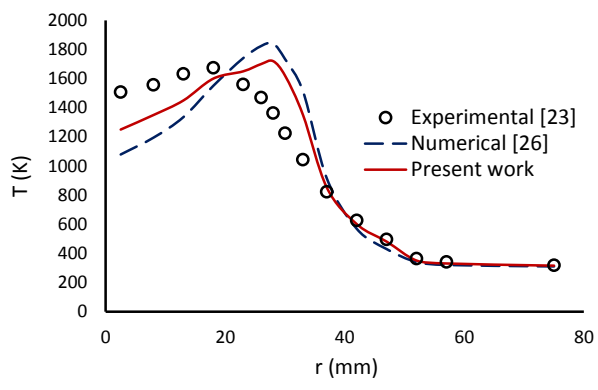

(c) $x=30 \mathrm{~cm}$

Fig. 2. Radial temperature distribution in the several axial positions, (a) at $15 \mathrm{~cm}$ axial distance, (b) at $20 \mathrm{~cm}$ axial distance, and (c) at $30 \mathrm{~cm}$ axial distance

\subsection{Comparison of two air/fuel velocity ratio cases}

Temperature contoured for the two cases are plotted in Fig. 3 (inlet air velocity $7 \mathrm{~m} / \mathrm{s}$ on the left side and air velocity $10 \mathrm{~m} / \mathrm{s}$ on the right side). It should be noted that in both cases, the fuel inlet velocity is $10 \mathrm{~m} / \mathrm{s}$ and $V_{F}$ and 
$V_{a}$ are denoted to fuel and air velocity, respectively. When the properties are considered variable and the relative velocity of air and fuel is low, as expected the mixing process become slower; similar to when the properties kept constant [26]. Thus, the flame length becomes smaller and the flame width turns out to be thicker; in other words, the flame temperature is low and extended into a large area in a computational domain.

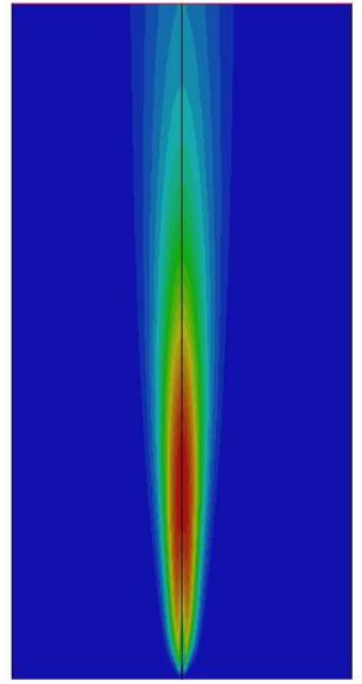

(a) $V_{a} / V_{F}=7 / 10$

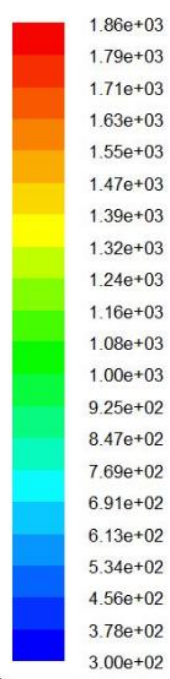

$.00 \mathrm{e}+02$
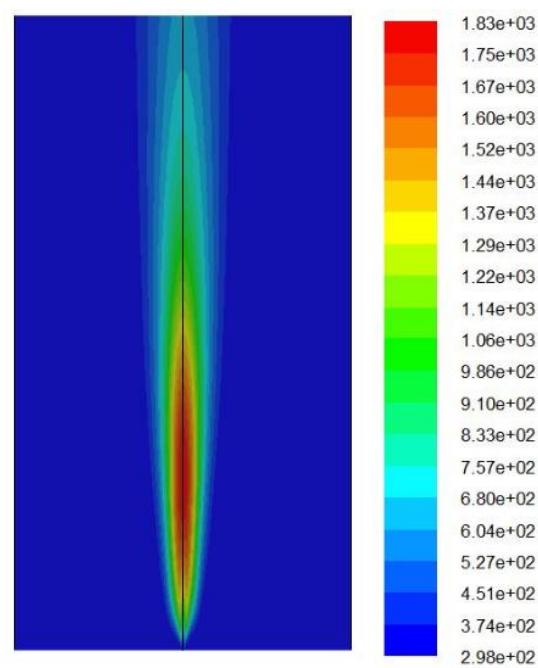

(b) $V_{a} / V_{F}=10 / 10=1$

Fig. 3. Temperature contour for two cases: a) $V_{F}=10 \mathrm{~m} / \mathrm{s}, V_{a}=7 \mathrm{~m} / \mathrm{s}$; b) $V_{F}=V_{a}=10 \mathrm{~m} / \mathrm{s}$

In Fig. 4, the radial distributions of temperature for several axial positions of the two cases are compared. When the relative velocities of air and fuel are high, the widths of graphs are smaller; this produces a smaller width of flame (or thinner flame) and a longer length of flame. By studying the temperature curves for both modes, it can be noted that with increasing air velocity, the flame length is increased; the flame becomes thinner and the maximum temperature is increased. For example, when the calculation was performed for the case with motionless air, it was observed that the flame was smaller, thicker, and the maximum temperature was lower. However, in this case, the flame was quite connected to the burner.

According to Fig. 4, it is observed that when air speeds up from 7 to $10 \mathrm{~m} / \mathrm{s}$, the local maximum temperature gets closer to the cylinder axis. The flame boundary is defined where the temperature is maximum and as a result, the flame is thinner.

Fig. 5 illustrates the mole fraction of methane for the two cases mentioned above for several axial positions. By considering the shape, it is observed that 


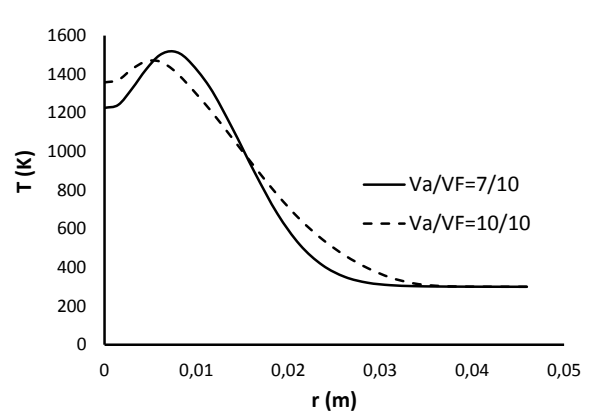

(a) $x=10 \mathrm{~cm}$

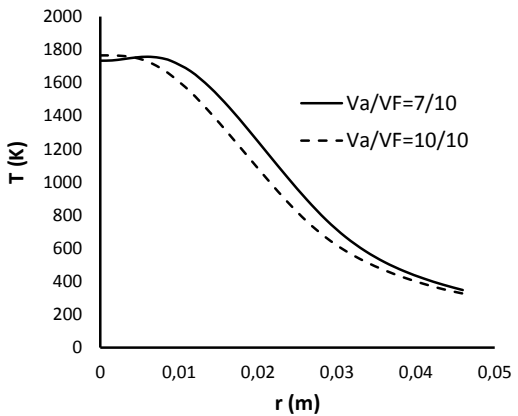

(b) $x=20 \mathrm{~cm}$

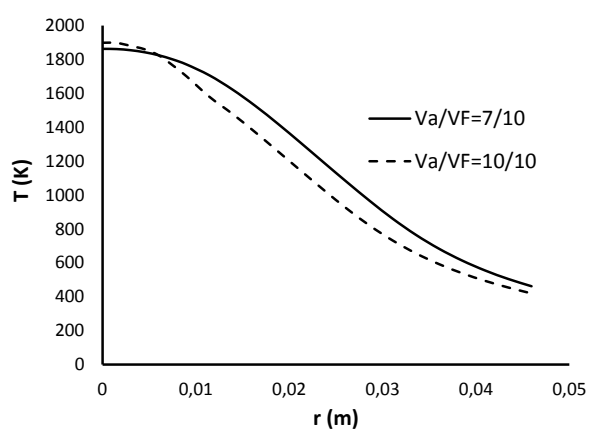

(c) $x=30 \mathrm{~cm}$

Fig. 4. Radial temperature distribution in the several axial positions

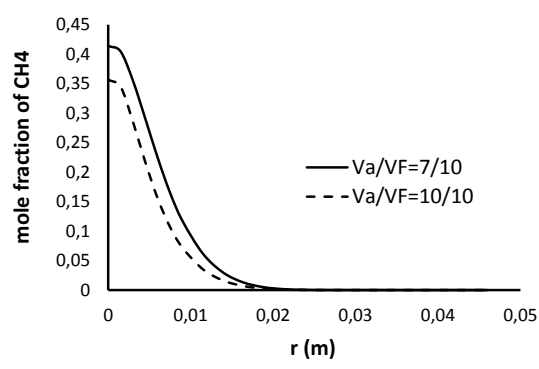

(a) $x=10 \mathrm{~cm}$

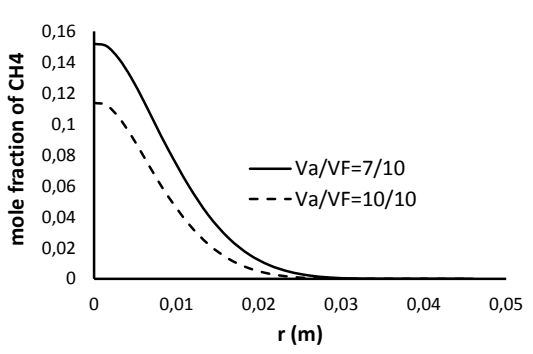

(b) $x=20 \mathrm{~cm}$

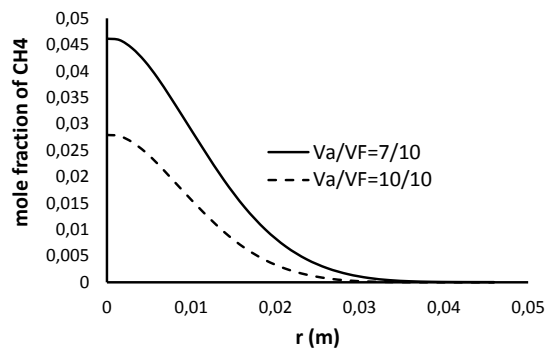

(c) $x=30 \mathrm{~cm}$

Fig. 5. Methane mole fraction for several axial positions in two different states 
with increasing air speed, as expected, similar to when the properties kept constant [26], fuel consumption is in the lower radial distance (i.e. methane mole fraction reaches zero); thus, this phenomenon indicates a thinner flame. The loss of the mole fraction of methane with increasing air velocity represents greater penetration of oxygen and products into the fuel. Fig. 6 shows the mole fraction of methane for the two cases mentioned in the several axial positions. It can be seen that when the distance from the inlet nozzle increases, the mole fraction of methane for both decreases and ultimately, the special mole fraction of methane in an axial position becomes zero. Based on the definition of the flame, the location of flame length can be specified.

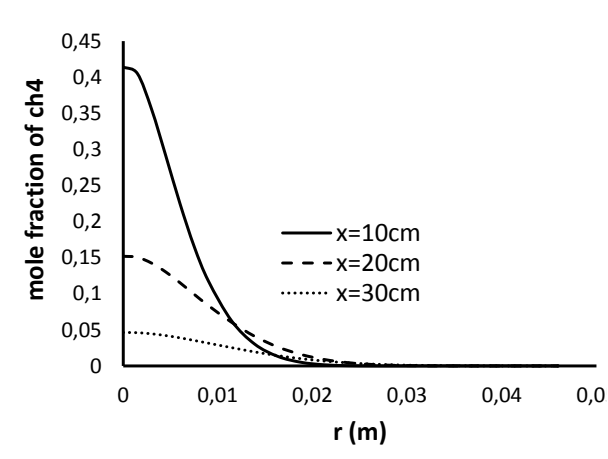

(a) $V_{a} / V_{F}=7 / 10$

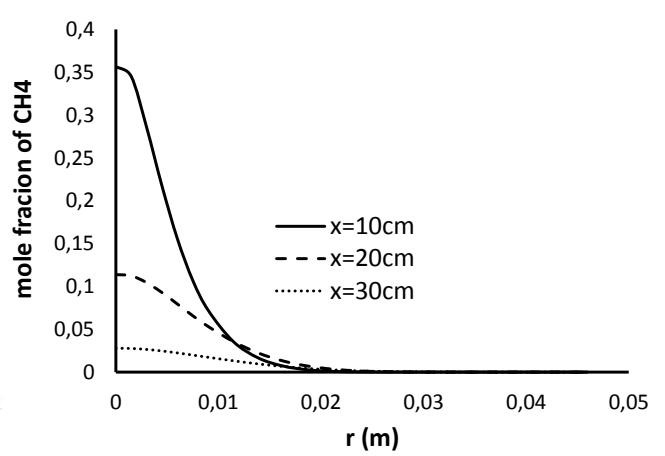

(b) $V_{a} / V_{F}=10 / 10$

Fig. 6. Methane mole fraction for two different states in several axial positions

Fig. 7 expresses the mole fraction of oxygen for the two cases mentioned above in several axial positions. As shown in Fig. 7, with increasing air velocity, more oxygen penetrates into the fuel. In this work, a combination of $21 \%$ oxygen and 79\% nitrogen in the air is considered. According to Fig. 7, when the air velocity increases, the amount of oxygen in the radial direction within the duct axis reaches its maximum. This produces a thinner flame when the air velocity is higher. Moreover, from Fig. 8, it is observed that the greater the distance is from the nozzle inlet, the more oxygen penetrates into the fuel, thereby increasing oxygen mole fraction.

At the end, it can be concluded that at certain flow rate of fuel when air velocity increases, the maximum flame temperature becomes higher, the flame gets thinner, more fuel is consumed, and more oxygen penetrates into the fuel. It is considerable that most of the pollutants produced are NOx, which is strongly temperature dependent. The amount of these pollutants increases when the temperature gets higher. Therefore, by decreasing the air velocity, the amount of these pollutants can be decreased. 


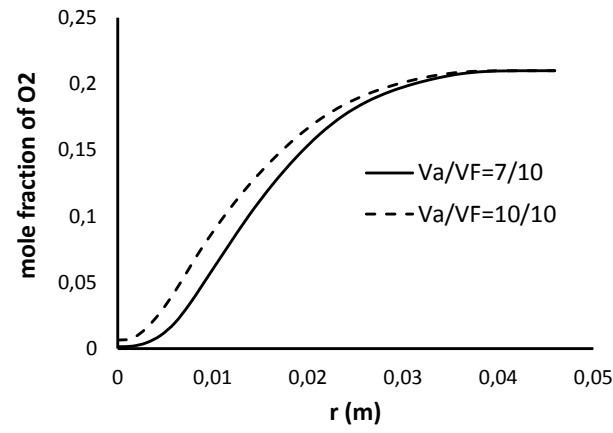

(a) $x=10 \mathrm{~cm}$

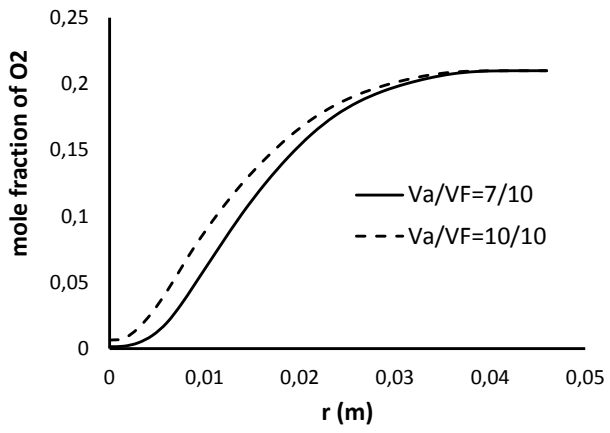

(b) $x=20 \mathrm{~cm}$

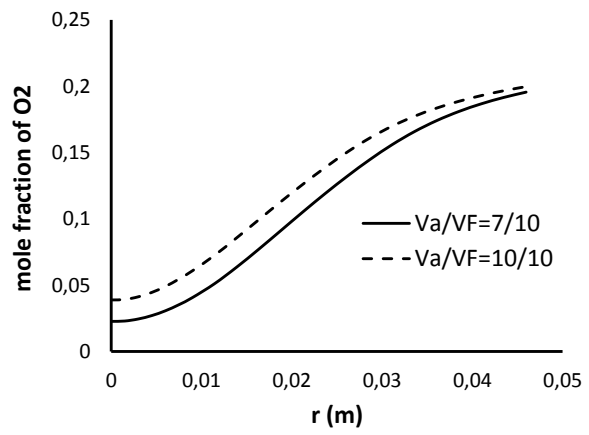

(c) $x=30 \mathrm{~cm}$

Fig. 7. Oxygen mole fraction for several axial positions in two different states

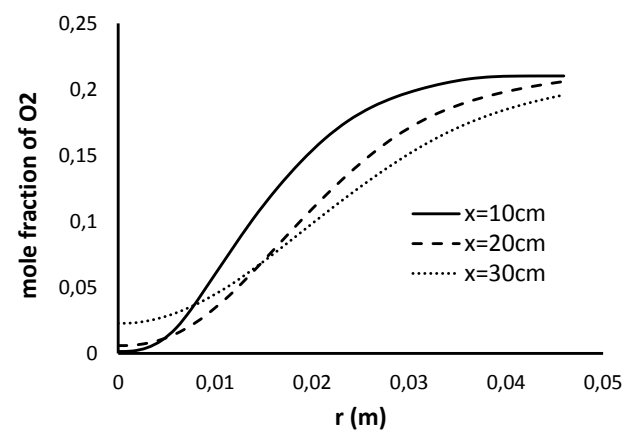

(a) $V_{a} / V_{F}=7 / 10$

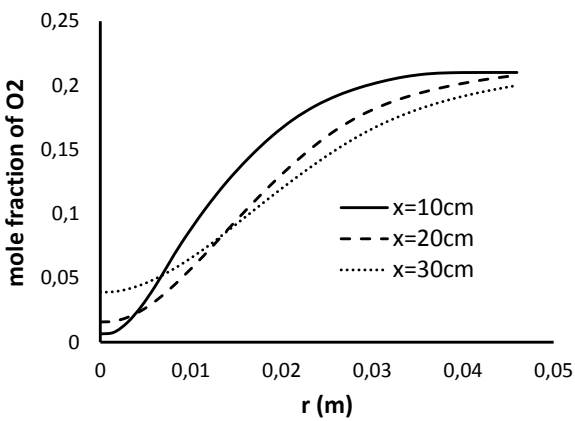

(b) $V_{a} / V_{F}=10 / 10$

Fig. 8. Oxygen mole fraction for two different states in several axial positions

\section{Conclusions}

In this research, the computational fluid dynamics is used to model the turbulent methane-air flame. This is to investigate the effect of air velocity on the length of the flame, the temperature distribution, and the mole fraction species by considering variable properties. The results show that, at certain 
flow rate of fuel, by increasing the air velocity, the width of flame becomes thinner and the maximum temperature gets higher; the penetration of oxygen into the fuel as well as fuel consumption is also increased. It is noteworthy that most of the pollutants produced are NOx, which are strongly temperature dependent. The amount of these pollutants rises when the temperature is increased. As a solution, decreasing the air velocity can decrease the amount of these pollutants. Finally, comparison the result of this work and another study, which considers constant properties, show that the variable properties assumption results in achieving more exact solution, though the trend of both the results are similar.

\section{Acknowledgements}

The authors acknowledge Yasooj branch, Islamic Azad University for its financial support to this project.

Manuscript received by Editorial Board, December 10, 2015;

final version, April 20, 2016.

\section{References}

[1] P.A. Libby and F.A. Williams. Fundamental aspects. In Turbulent reacting flows, chapter 1, pages 1-43. Springer, 1980.

[2] F.A. Williams. Progress in knowledge of flamelet structure and extinction. Progress in Energy and Combustion Science, 26(4):657-682, 2000.

[3] R.W. Bilger. Future progress in turbulent combustion research. Progress in Energy and Combustion Science, 26(4):367-380, 2000.

[4] W.P. Jones and J.H. Whitelaw. Calculation methods for reacting turbulent flows: a review. Combustion and Flame, 48:1-26, 1982.

[5] N. Peters. Turbulent combustion. Cambridge University Press, 2000.

[6] B.E. Launder, G. Jr. Reece, and W. Rodi. Progress in the development of a Reynolds-stress turbulence closure. Journal of Fluid Mechanics, 68(03):537-566, 1975.

[7] N. Peters. Laminar flamelet concepts in turbulent combustion. In Symposium (International) on Combustion, volume 21, pages 1231-1250. Elsevier, 1988.

[8] S.B. Pope. PDF methods for turbulent reactive flows. Progress in Energy and Combustion Science, 11(2):119-192, 1985.

[9] R.W. Bilger. Conditional moment closure for turbulent reacting flow. Physics of Fluids A: Fluid Dynamics), 5(2):436-444, 1993.

[10] S. Mahesh and D.P. Mishra. Flame stability and emission characteristics of turbulent LPG IDF in a backstep burner. Fuel, 87(12):2614-2619, 2008.

[11] S. Mahesh and D.P. Mishra. Flame structure of LPG-air Inverse Diffusion Flame in a backstep burner. Fuel, 89(8):2145-2148, 2010.

[12] E. Fernández-Tarrazo, M. Vera, and A. Liñán. Liftoff and blowoff of a diffusion flame between parallel streams of fuel and air. Combustion and Flame, 144(1):261-276, 2006.

[13] P. Meunier, M. Costa, and M.G. Carvalho. On NOx emissions from turbulent propane diffusion flames. Combustion and Flame, 112(1):221-230, 1998. 
[14] A. Santos and M. Costa. Reexamination of the scaling laws for NOx emissions from hydrocarbon turbulent jet diffusion flames. Combustion and Flame, 142(1):160-169, 2005.

[15] A. Sobiesiak and J.C. Wenzell. Characteristics and structure of inverse flames of natural gas. Proceedings of the Combustion Institute, 30(1):743-749, 2005.

[16] L.K. Sze, C.S. Cheung, and C.W. Leung. Appearance, temperature, and NOx emission of two inverse diffusion flames with different port design. Combustion and Flame, 144(1):237-248, 2006.

[17] J. Oh, P. Heo, and Y. Yoon. Acoustic excitation effect on NOx reduction and flame stability in a lifted non-premixed turbulent hydrogen jet with coaxial air. International Journal of Hydrogen Energy, 34(18):7851-7861, 2009.

[18] D.P. Mishra and P. Kumar. Experimental study of bluff-body stabilized LPG-H2 jet diffusion flame with preheated reactant. Fuel, 89(1):212-218, 2010.

[19] W. Rudy, A. Dabkowski, and A. Teodorczyk. Experimental and numerical study on spontaneous ignition of hydrogen and hydrogen-methane jets in air. International Journal of Hydrogen Energy, 39(35):20388-20395, 2014.

[20] S.A.A. El-Ghafour, A.H.E. El-Dein, and A.A.R. Aref. Combustion characteristics of natural gas-hydrogen hybrid fuel turbulent diffusion flame. International Journal of Hydrogen Energy, 35(6):2556-2565, 2010.

[21] K.W. Lee and D.H. Choi. Analysis of NO formation in high temperature diluted air combustion in a coaxial jet flame using an unsteady flamelet model. International Journal of Heat and Mass Transfer, 52(5):1412-1420, 2009.

[22] G.M. Choi and M. Katsuki. Advanced low NOx combustion using highly preheated air. Energy Conversion and Management, 42(5):639-652, 2001.

[23] S.J. Brookes and J.B. Moss. Measurements of soot production and thermal radiation from confined turbulent jet diffusion flames of methane. Combustion and Flame, 116(1):49-61, 1999.

[24] T. Boushaki, M.A. Mergheni, J.C. Sautet, and B. Labegorre. Effects of inclined jets on turbulent oxy-flame characteristics in a triple jet burner. Experimental Thermal and Fluid Science, 32(7):1363-1370, 2008.

[25] Z. Namazin. Effect of air velocity on the length of flame in turbulent non-premixed flames. In Proceedings of 15th ISERD International Conference, pages 25-28, Rome, Italy, Nov. 2015.

[26] Z. Riahi, M.A. Mergheni, J.C. Sautet, and S.B. Nasrallah. Numerical study of turbulent normal diffusion flame CH4-air stabilized by coaxial burner. Thermal Science, 17(4):1207-1219, 2013.

\section{Badanie wpływu szybkości powietrza w płomieniach turbulentnych bez wstępnego mieszania}

Streszczenie

W pracy przeprowadzono symulację turbulentnego płomienia metanowo-powietrznego bez mieszania wstępnego w celu wyznaczenia wpływu szybkości powietrza na długość płomienia, rozkład temperatur oraz ułamek molowy składników spalin. Do przeprowadzenia symulacji wykorzystano technikę obliczeniowej dynamiki płynów (CFD). Przy rozwiązaniu przepływu turbulentnego zasto-

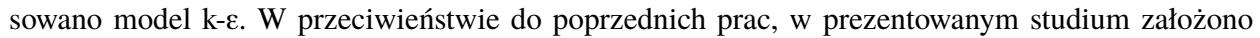
zmienne właściwości materiałów w każdej z symulacji, a wyniki symulacji porównywano. Rezultaty badań pokazują, że przy określonej prędkości przepływu paliwa, przy wzroście szybkości powietrza uzyskuje się cieńszy płomień, o wyższej temperaturze, podobnie jak w przypadku gdy zakłada się stałe właściwości. Wzrasta przy tym penetracja tlenu do płomienia, a także zużycie paliwa. Warto zauważyć, że większość powstających szkodliwych substancji to tlenki azotu (NOx), silnie zależne 
od temperatury. Zawartość tych zanieczyszczeń rośnie ze wzrostem temperatury. Rozwiązaniem jest zmniejszenie szybkości powietrza, co może zmniejszyć zawartość zanieczyszczeń. Ostatecznie, porównując wyniki tego studium i poprzedniej pracy gdzie założono stałe właściwości materiałów, pokazano, że założenie zmiennych właściwości prowadzi do otrzymania dokładniejszych rozwiązań, niemniej, wyniki wykazują w obydwu przypadkach ten sam trend. 